\title{
Effect of Ethanol Stress on Fermentation Performance of Saccharomyces cerevisiae Cells Immobilized on Nypa fruticans Leaf Sheath Pieces
}

\author{
Hoang Phong Nguyen, Hoang Du Le and Van Viet Man Le* \\ Department of Food Technology, Ho Chi Minh City University of Technology, \\ 268 Ly Thuong Kiet Street, District 10, 70000 Ho Chi Minh City, Vietnam
}

Received: February 16, 2014

Accepted: November 7, 2014

\begin{abstract}
Summary
The yeast cells of Saccharomyces cerevisiae immobilized on Nypa fruticans leaf sheath pieces were tested for ethanol tolerance (0, 23.7, 47.4, 71.0 and $94.7 \mathrm{~g} / \mathrm{L})$. Increase in the initial ethanol concentration from 23.7 to $94.7 \mathrm{~g} / \mathrm{L}$ decreased the average growth rate and concentration of ethanol produced by the immobilized yeast by 5.2 and 4.1 times, respectively. However, in the medium with initial ethanol concentration of $94.7 \mathrm{~g} / \mathrm{L}$, the average growth rate, glucose uptake rate and ethanol formation rate of the immobilized yeast were 3.7, 2.5 and 3.5 times, respectively, higher than those of the free yeast. The ethanol stress inhibited ethanol formation by Saccharomyces cerevisiae cells and the yeast responded to the stress by changing the fatty acid composition of cellular membrane. The adsorption of yeast cells on Nypa fruticans leaf sheath pieces of the growth medium increased the saturated fatty acid (C16:0 and C18:0) mass fraction in the cellular membrane and that improved alcoholic fermentation performance of the immobilized yeast.
\end{abstract}

Key words: Saccharomyces cerevisiae, immobilized yeast, ethanol stress, Nypa fruticans, fatty acids

\section{Introduction}

The use of immobilized cells of Saccharomyces cerevisiae in ethanol fermentation has attracted considerable attention in the last few decades (1). The immobilization of yeast protected the cells against environmental stresses such as low $\mathrm{pH}$, high temperature, high osmotic pressure and high ethanol concentration in the culture $(2,3)$. As a result, the immobilized cell system improved ethanol productivity and reduced production cost in comparison with the free cells $(3,4)$. Conventionally, polymeric gel carriers have been used for yeast cell immobilization (1). However, some gel carriers would militate against substrate diffusion into the immobilized cells and therefore decrease metabolic activity of the biocatalysts (5). In an effort to facilitate the diffusion of substrates into the immobilized cells, many studies have been done with Sac- charomyces cerevisiae cells adsorbed on high cellulosic materials with highly porous structure such as bagasse (1), cashew apple bagasse (2) and sugarcane pieces (3). According to Liang et al. (3), cell systems immobilized on supports with high cellulosic content exhibited many advantages such as the use of cheap carriers, the simplicity and low cost of the immobilization techniques and the stability of the immobilized biocatalyst in ethanol fermentation conditions. In this work, Nypa fruticans leaf sheath pieces were used as new support for immobilization of Saccharomyces cerevisiae cells for ethanol fermentation.

Nipa (Nypa fruticans) is one of the most common, widely distributed, and useful palms in the mangrove forests of South and Southeast Asia. Young seeds are eaten raw or preserved in syrup. Nipa palm leaves have traditionally been harvested for roof thatching and walls of dwellings. The leaf sheath has also been used in insula- 
tion boards (6). Due to highly porous structure (7), we suggested that nipa leaf sheath pieces can be used as a support for yeast immobilization. There has been no study on the immobilization of microbial cells on Nypa fruticans leaf sheath pieces.

Under environmental stresses, the yeast immobilized in gel carriers exhibited better ethanol tolerance than the free yeast (8) and that was due to the protection of the carrier. In addition, under ethanol stress, the survival and metabolism of the cells depend on their ability to adapt quickly to the stress (9). Changes in fatty acid composition in cellular membrane may be a response of the yeast to environmental stress and some authors believed that these changes would improve ethanol tolerance of the yeast. These studies, however, were mostly done with the free yeast $(10,11)$. No research has been done to investigate the changes of membrane fatty acid composition of the immobilized yeast on cellulosic material under ethanol stress.

The aim of this research is to investigate the effects of ethanol stress on the growth of, sugar assimilation and ethanol formation by $S$. cerevisiae cells immobilized on Nypa fruticans leaf sheath pieces. Fermentation performance of the free cells under the same conditions was also investigated as control. Membrane fatty acid composition of the yeast cells was determined to provide a clearer understanding about the response of immobilized $S$. cerevisiae to ethanol stress.

\section{Materials and Methods}

\section{Yeast and media}

Saccharomyces cerevisiae TG1 originating from the culture collection of the Food Technology Department, Ho Chi Minh City University of Technology, Vietnam, was used for ethanol fermentation. For the inoculum preparation, the yeast strain was cultivated in $10 \mathrm{~mL}$ of growth medium containing (in g/L): glucose 30, yeast extract 5, $\mathrm{NH}_{4} \mathrm{Cl} 1, \mathrm{KH}_{2} \mathrm{PO}_{4} 1$ and $\mathrm{MgSO}_{4} \cdot 7 \mathrm{H}_{2} \mathrm{O} 5$ in a test tube $(150$ $\mathrm{mm} \times 16 \mathrm{~mm})$. The test tube was shaken at $30^{\circ} \mathrm{C}$ and $350 \times g$ for $24 \mathrm{~h}$. Then, $10 \mathrm{~mL}$ of the preculture were inoculated into a 250-mL Erlenmeyer flask containing $90 \mathrm{~mL}$ of growth medium. The flask was also shaken at $30^{\circ} \mathrm{C}$ and $350 \times g$ for $24 \mathrm{~h}$. The preculture were subsequently centrifuged at $2800 \times g$ and $5{ }^{\circ} \mathrm{C}$ for $20 \mathrm{~min}$. Yeast cells were collected and washed with sterile water. Then they were used for immobilization on leaf sheath pieces of Nypa fruticans or for ethanol fermentation as control sample.

The medium composition for yeast immobilization and ethanol fermentation was similar to that for preculture preparation, except for the glucose level. The glucose concentration in the media for yeast immobilization and ethanol fermentation was adjusted to 120 and $200 \mathrm{~g} / \mathrm{L}$, respectively. The initial $\mathrm{pH}$ value of the media was 5.5. All media were sterilized at $121^{\circ} \mathrm{C}$ for $20 \mathrm{~min}$ before use.

\section{Carrier}

Leaf sheath pieces of Nypa fruticans were used as carriers for yeast immobilization. Firstly, the leaf sheath was washed with potable water and then cut into $0.5 \mathrm{~cm}$ high,
$2 \mathrm{~cm}$ wide and $3 \mathrm{~cm}$ long cubic shapes. The leaf sheath pieces were then sterilized at $121^{\circ} \mathrm{C}$ for $20 \mathrm{~min}$ before use.

\section{Yeast immobilization on Nypa fruticans leaf sheath pieces}

A mass of $20 \mathrm{~g}$ of sterilized leaf sheath pieces and 100 $\mathrm{mL}$ of medium for yeast immobilization were added into a $250-\mathrm{mL}$ shaking flask. The yeast biomass was introduced into the flasks in order to reach a cell density of 3.0 $10^{7} \mathrm{CFU} / \mathrm{mL}$. The flasks were then shaken at $320 \times g$ and $30{ }^{\circ} \mathrm{C}$ for $20 \mathrm{~h}$. The liquid fraction was decanted and the leaf sheath pieces with immobilized cells were washed with the fermentation medium twice. The immobilized biocatalyst was sampled for cell quantification.

\section{Ethanol fermentation}

Ethanol fermentations were carried out under static conditions. The immobilized yeast was introduced into 500 -mL flasks containing $250 \mathrm{~mL}$ of medium with the inoculum size of $10^{7} \mathrm{CFU} / \mathrm{mL}$. The initial ethanol concentration in the medium was varied: $0,23.7,47.4,71.0$ and 94.7 $\mathrm{g} / \mathrm{L}$. Fermentations were carried out until the residual sugar level did not change during 12 consecutive hours. During the fermentation, samples were taken at 12-hour intervals for analysis. The fermentations with the free yeast were also performed under the same conditions.

\section{Analytical methods}

Determination of total dietary fibre of Nypa fruticans leaf sheath, yeast cell density, and glucose and ethanol concentrations

Total dietary fibre of Nypa fruticans leaf sheath was determined by enzymatic-gravimetric method (12). The yeast cell concentration in liquid sample was determined by incubating the plate count agar at $30^{\circ} \mathrm{C}$ for $48 \mathrm{~h}$ (2). The immobilized cells adsorbed on the leaf sheath pieces were quantified by the procedure described previously (13) with slight modification. A volume of $90 \mathrm{~mL}$ of sterile water and $10 \mathrm{~g}$ of leaf sheath pieces with the immobilized cells were ground in a grinder at $1750 \times g$ for $5 \mathrm{~min}$. The cell number in the obtained suspension was determined by incubating the plate count agar at $30^{\circ} \mathrm{C}$ for $48 \mathrm{~h}$.

Glucose concentration was quantified by spectrophotometric method with 3,5-dinitrosalicylic acid reagent (14). Ethanol concentration was quantified by enzymatic method using ethanol kit with a reflectometer model 116970 (Merck KGaA, Darmstadt, Germany). Under the catalytic effect of alcohol dehydrogenase, ethanol was oxidized by nicotinamide adenine dinucleotide (NAD) to acetaldehyde. In the presence of an electron transmitter, the NADH formed in the process reduced a tetrazolium salt to a blue formazan, which was determined reflectometrically.

Fatty acid composition of yeast cell membrane

Prior to determination of fatty acid composition, the lipid fraction was extracted from the yeast cell membrane by the previously described method (9) with slight modification. Mixture of yeast biomass and methanol was 
treated with ultrasound using a model VC 750 ultrasonic probe (Sonics \& Materials Inc., Newtown, CT, USA) at an ultrasonic power of $5 \mathrm{~W} / \mathrm{g}$ for $1 \mathrm{~min}$ to break down the cell walls. The lipid extraction was then carried out by adding chloroform and methanol ( $2: 1$ by volume) to the sonicated mixture. The mass per volume ratio of material to solvent was $5: 2$. The extraction was performed at the agitation rate of $480 \times g$ for $2 \mathrm{~h}$. The organic phase was then transferred into a glass screw tube containing $0.88 \% \mathrm{KCl}$ solution. The mixture was centrifuged at $1000 \times g$ and 25 ${ }^{\circ} \mathrm{C}$ for $5 \mathrm{~min}$. The organic phase was then collected and used for determination of fatty acid composition.

Fatty acid composition was determined by gas chromatography using a Hewlett-Packard model 5890A gas chromatograph (Hewlett-Packard, Minneapolis, MN, USA). The extract was injected into an FFAP-HP column of 25 $\mathrm{m} \times 0.2 \mathrm{~mm}$ with an HP automatic injector. Helium was used as carrier gas at $1.0 \mathrm{~mL} / \mathrm{min}$ and heptadecanoic acid methyl ester $(1 \mu \mathrm{g} / \mu \mathrm{L})$ was added as an internal standard. Column inlet pressure was $150 \mathrm{kPa}$. The injector temperature was $250{ }^{\circ} \mathrm{C}$. Detector temperature was $250{ }^{\circ} \mathrm{C}$. The temperature program was $25^{\circ} \mathrm{C} / \mathrm{min}$ from 70 to $200{ }^{\circ} \mathrm{C}$. Peak areas were measured using a Hewlett-Packard model 3396A integrator.

Unsaturation degree of fatty acids in yeast cell membrane was calculated using the formula described previously (15).

Average growth rate, sugar uptake rate and ethanol formation rate of the immobilized and free yeast

The average growth rate, sugar uptake rate and ethanol formation rate were calculated using the following formulas:

Average growth rate $/(\mathrm{CFU} /(\mathrm{mL} \cdot \mathrm{h}))=\frac{N(\text { cell })_{\max }-N(\text { cell })_{\text {initial }}}{t_{1}} / 1 /$

Sugar uptake rate $/(\mathrm{g} /(\mathrm{L} \cdot \mathrm{h}))=\frac{\gamma(\text { sugar })_{\text {initial }}-\gamma(\text { sugar })_{\text {residual }}}{t_{2}} / 2 /$

Ethanol formation rate $/(\mathrm{g} /(\mathrm{L} \cdot \mathrm{h}))=\frac{\gamma(\text { ethanol })_{\text {produced }}}{t_{2}}$

where $t_{1}$ was the fermentation time $(\mathrm{h})$ after which the cell density in the culture achieved maximum, and $t_{2}$ was the fermentation time (h) after which the residual sugar content in the culture did not change.

\section{Statistical analysis}

All experiments were performed in triplicate. Mean values were considered significantly different when $p<0.05$. One-way and multi-way analyses of variance were performed using the Statgraphics Centurion XV software (Statpoint Technologies, Inc., Warrenton, VA, USA).

\section{Results and Discussion}

\section{Effects of ethanol stress on yeast growth}

In this study, the growth of $S$. cerevisiae was estimated by average growth rate and maximum cell density. Table 1 shows that the maximum cell density and the average growth rate were not significantly different when the initial ethanol concentration increased from 0 to $23.7 \mathrm{~g} / \mathrm{L}$. This phenomenon was observed for both the immobilized and free yeast. Increase in the initial ethanol concentration from 23.7 to $94.7 \mathrm{~g} / \mathrm{L}$ decreased the growth rate of the immobilized and free cells by 5.2 and 17.2 times, respectively. Ethanol was reported to inhibit glycolytic enzymes and biological processes which were associated with lipid synthesis in the cellular membrane (16). In addition, ethanol could remove hydrate layers around yeast cells (17) and decrease water activity of the medium (18). As a result, ethanol reduced the growth of yeast cells. Similar observations were reported in a previous study (19) when $S$. cerevisiae cells fixed on cellulose beads were used for ethanol fermentation under ethanol stress.

Maximum cell density and average growth rate of the yeast immobilized on Nypa fruticans leaf sheath pieces were always higher than those of the free yeast. Similar observations were also reported for S. cerevisiae cells fixed on cellulose beads as the fermentations were performed under ethanol stress (19). In the present study, the maximum cell density and average growth rate of the immobilized yeast in the medium with ethanol concentration of $94.7 \mathrm{~g} / \mathrm{L}$ were 1.8 and 3.7 times higher, respectively, than those of the free yeast. Our preliminary studies showed that the total dietary fibre mass fraction in Nypa fruticans leaf sheath pieces was $61.6 \%$ on dry matter basis. Carriers with high carbohydrate level could protect the hydrate layer around yeast cells from ethanol (17). In addition, at the start of the fermentation, the cell density in the support was $7.5 \cdot 10^{9} \mathrm{CFU}$ per $\mathrm{g}$ of dried support. It was reported that due to high density of immobilized cells on the carrier, the yeast cells protected each other against etha-

Table 1. Effect of ethanol stress on yeast growth

\begin{tabular}{|c|c|c|c|c|}
\hline \multirow{2}{*}{$\frac{\gamma(\text { ethanol })_{\text {initial }}}{\mathrm{g} / \mathrm{L}}$} & \multicolumn{2}{|c|}{$\frac{N(\text { cell })_{\max }}{10^{6} \mathrm{CFU} / \mathrm{mL}}$} & \multicolumn{2}{|c|}{$\frac{\text { Average growth rate }}{10^{6} \mathrm{CFU} /(\mathrm{mL} \cdot \mathrm{h})}$} \\
\hline & Immobilized cells & Free cells & Immobilized cells & Free cells \\
\hline 0 (control) & $(138.5 \pm 5.3)^{\mathrm{m}}$ & $(102.7 \pm 3.8)^{\mathrm{k}}$ & $(3.8 \pm 0.3)^{\mathrm{f}}$ & $(3.1 \pm 0.2)^{\mathrm{e}}$ \\
\hline 23.7 & $(133.5 \pm 5.0)^{\mathrm{m}}$ & $(98.3 \pm 4.1)^{\mathrm{k}}$ & $(3.6 \pm 0.3)^{f}$ & $(2.9 \pm 0.2)^{\mathrm{e}}$ \\
\hline 47.4 & $(120.7 \pm 4.2)^{1}$ & $(86.7 \pm 3.9)^{j}$ & $(2.4 \pm 0.3)^{\mathrm{d}}$ & $(1.8 \pm 0.2)^{\mathrm{c}}$ \\
\hline 71.0 & $(45.8 \pm 2.1)^{\mathrm{i}}$ & $(22.2 \pm 1.0)^{\mathrm{h}}$ & $(1.6 \pm 0.1)^{c}$ & $(0.56 \pm 0.09)^{b}$ \\
\hline 94.7 & $(21.5 \pm 0.6)^{\mathrm{h}}$ & $(12.1 \pm 0.2)^{g}$ & $(0.6 \pm 0.1)^{\mathrm{b}}$ & $(0.17 \pm 0.01)^{\mathrm{a}}$ \\
\hline
\end{tabular}

Superscripts in table indicate significant difference $(\mathrm{p}<0.05)$. Results are presented as mean values \pm standard deviations for $N=3$ 
nol and that led to an improvement in ethanol tolerance of the immobilized yeast (5).

\section{Effect of ethanol stress on glucose assimilation by Saccharomyces cerevisiae}

Table 2 shows that the glucose uptake rate by the free yeast decreased when the initial ethanol concentration in the medium augmented from 23.7 to $94.7 \mathrm{~g} / \mathrm{L}$. The glucose uptake rate of the immobilized yeast slowed down as the initial ethanol concentration increased from 47.4 to $94.7 \mathrm{~g} / \mathrm{L}$. At the initial ethanol concentration of $94.7 \mathrm{~g} / \mathrm{L}$, glucose uptake rate of the immobilized yeast was 2.5 times higher than that of the free yeast. The immobilized cells were consequently more tolerant to ethanol than the free cells. The residual sugar level in the culture with both free and immobilized yeast increased as the initial ethanol concentration increased from 0 to $94.7 \mathrm{~g} / \mathrm{L}$. It was reported that high ethanol concentration could reduce the sugar assimilation of the immobilized (17) and free cells of S. cerevesiae (20). High level of ethanol accumulated in the fermented cultures would limit the transport of glucose into the cells (21). As a result, ethanol decreased metabolic activity of both immobilized and free yeast cells.

When the initial ethanol concentration increased from 0 to $94.7 \mathrm{~g} / \mathrm{L}$, the glucose uptake rate of the immobilized yeast was significantly faster than that of the free yeast. In addition, the immobilized yeast had lower residual sugar level than the free yeast at all investigated ethanol concentrations. There have not been any studies to compare glucose uptake rate of $S$. cerevisiae cells immobilized on cellulosic materials and free cells under ethanol stress. In the case of $S$. cerevisiae yeast entrapped in gelatin gel, the immobilized cells assimilated glucose twice as fast as the suspended cells (22) when the fermentation was performed in the medium without ethanol addition.
It was reported that the adaptation of the immobilized yeast to the changes in medium composition was faster than that of the free yeast (23). Hence, the immobilized yeast assimilated sugar faster than the free yeast.

\section{Effects of ethanol stress on ethanol formation by Saccharomyces cerevisiae}

Table 3 shows that increase in the initial ethanol concentration from 0 to $94.7 \mathrm{~g} / \mathrm{L}$ decreased the level of produced ethanol and ethanol formation rate of the free yeast. The concentration of ethanol produced by the immobilized cells and ethanol formation rate were reduced as the initial ethanol concentration augmented from 23.7 to $94.7 \mathrm{~g} / \mathrm{L}$. In the medium without ethanol addition, the concentration of produced ethanol by the immobilized yeast was 1.2 times higher than that by the free yeast. When the initial ethanol concentration increased from 23.7 to $94.7 \mathrm{~g} / \mathrm{L}$, the concentration of ethanol produced by the immobilized and the free yeast decreased 4.1 and 12.9 times, respectively. In addition, the results in Table 3 also show that the ethanol formation rate by the immobilized yeast was significantly higher than that by the free yeast. At $94.7 \mathrm{~g} / \mathrm{L}$ of ethanol, the ethanol formation rate by the immobilized yeast was 3.5 times higher than that by the free yeast. Some previous studies also reported that $S$. cerevisiae cells immobilized on sugarcane pieces (3) and on corn stem (23) produced more ethanol and exhibited higher ethanol formation rate than the free yeast when the fermentations were performed in media without ethanol addition.

Improvement in ethanol tolerance of free $S$. cerevisiae cells was previously explained through changes in fatty acid composition in cellular membrane $(9,24-28)$. Our preliminary studies showed that the mass fractions of palmitic (C16:0), stearic (C18:0), palmitoleic (C16:1) and

Table 2. Effect of ethanol stress on glucose assimilation by Saccharomyces cerevisiae

\begin{tabular}{|c|c|c|c|c|}
\hline \multirow{2}{*}{$\frac{\gamma(\text { ethanol })_{\text {initial }}}{\mathrm{g} / \mathrm{L}}$} & \multicolumn{2}{|c|}{ Sugar uptake rate/(g/(L·h)) } & \multicolumn{2}{|c|}{$\gamma(\text { sugar })_{\text {residual }} /(\mathrm{g} / \mathrm{L})$} \\
\hline & Immobilized cells & Free cells & Immobilized cells & Free cells \\
\hline 0 (control) & $(3.9 \pm 0.2)^{f}$ & $(2.7 \pm 0.1)^{\mathrm{e}}$ & $(0.83 \pm 0.03)^{\mathrm{a}}$ & $(5.6 \pm 0.1)^{g}$ \\
\hline 23.7 & $(3.9 \pm 0.2)^{f}$ & $(2.7 \pm 0.1)^{\mathrm{e}}$ & $(1.55 \pm 0.03)^{c}$ & $(6.10 \pm 0.08)^{\mathrm{h}}$ \\
\hline 47.4 & $(3.8 \pm 0.2)^{\mathrm{f}}$ & $(2.0 \pm 0.1)^{\mathrm{d}}$ & $(38.7 \pm 1.1)^{\mathrm{i}}$ & $(90.1 \pm 2.0)^{\mathrm{j}}$ \\
\hline 71.0 & $(2.8 \pm 0.1)^{\mathrm{e}}$ & $(1.7 \pm 0.1)^{c}$ & $(77.8 \pm 2.9)^{j}$ & $(141.8 \pm 2.3)^{1}$ \\
\hline 94.7 & $(2.6 \pm 0.1)^{\mathrm{e}}$ & $(1.05 \pm 0.02)^{\mathrm{b}}$ & $(141.5 \pm 1.9)^{\mathrm{k}}$ & $(180.4 \pm 2.4)^{\mathrm{m}}$ \\
\hline
\end{tabular}

Superscripts indicate significant difference $(\mathrm{p}<0.05)$. Results are presented as mean values \pm standard deviations for $N=3$

Table 3. Effects of ethanol stress on ethanol formation by Saccharomyces cerevisiae

\begin{tabular}{|c|c|c|c|c|}
\hline \multirow{2}{*}{$\frac{\gamma(\text { ethanol })_{\text {initial }}}{\mathrm{g} / \mathrm{L}}$} & \multicolumn{2}{|c|}{$\gamma(\text { ethanol })_{\text {produced }} /(\mathrm{g} / \mathrm{L})$} & \multicolumn{2}{|c|}{ Ethanol formation rate $/(\mathrm{g} /(\mathrm{L} \cdot \mathrm{h}))$} \\
\hline & Immobilized cells & Free cells & Immobilized cells & Free cells \\
\hline 0 (control) & $(95.5 \pm 3.2)^{\circ}$ & $(85.3 \pm 3.9)^{\mathrm{n}}$ & $(2.2 \pm 0.1)^{\mathrm{h}}$ & $(2.01 \pm 0.08)^{g}$ \\
\hline 23.7 & $(96.3 \pm 3.9)^{\circ}$ & $(71.0 \pm 1.6)^{\mathrm{m}}$ & $(2.3 \pm 0.1)^{\mathrm{h}}$ & $(1.87 \pm 0.01)^{\mathrm{f}}$ \\
\hline 47.4 & $(67.9 \pm 3.2)^{\mathrm{m}}$ & $(38.7 \pm 1.6)^{1}$ & $(1.82 \pm 0.08)^{\mathrm{f}}$ & $(1.06 \pm 0.05)^{\mathrm{e}}$ \\
\hline 71.0 & $(40.3 \pm 2.4)^{1}$ & $(16.6 \pm 0.8)^{j}$ & $(0.83 \pm 0.05)^{\mathrm{d}}$ & $(0.41 \pm 0.02)^{\mathrm{c}}$ \\
\hline 94.7 & $(23.7 \pm 1.6)^{\mathrm{k}}$ & $(5.5 \pm 0.2)^{\mathrm{i}}$ & $(0.07 \pm 0.01)^{\mathrm{b}}$ & $(0.02 \pm 0.00)^{\mathrm{a}}$ \\
\hline
\end{tabular}

Superscripts indicate significant difference $(\mathrm{p}<0.05)$. Results are presented as mean values \pm standard deviations for $N=3$ 
oleic (C18:1) acids in cellular membrane of $S$. cerevisiae TG1 used in this work were dominant in comparison with those of other fatty acids. In the medium without ethanol addition, increase in saturated fatty acid (C16:0 and C18:0) mass fraction and decrease in unsaturated fatty acid (C16:1 and C18:1) mass fraction in the free yeast cells were observed at the end of fermentation (Fig. 1; bars A, B and $\mathrm{C}$ ). Our results are in agreement with the previous findings (29) where S. cerevisiae NCYC 431 was used for ethanol fermentation. However, it was reported that mass fractions of stearic, palmitoleic and oleic acids in cellular membrane of free $S$. cerevisiae IMM 30 cells remained constant during ethanol fermentation (26). Fig. 1 (bars A, B and C) also shows that in the medium with $47.4 \mathrm{~g} / \mathrm{L}$ of ethanol, changes in both saturated and unsaturated fatty acid mass fractions in yeast cell membrane were similar to those in the medium without ethanol addition. This observation was in contrast with the findings of some authors who concluded that the relative percentage of palmitic and stearic acids decreased when fermentation proceeded with $S$. cerevisiae LH 02/2 (11). The differences between our results and the findings of other authors $(11,26)$ were possibly due to the difference in yeast strain.

No study has been done to investigate the effects of initial ethanol concentration in the medium on fatty acid composition of the immobilized yeast at the end of the fermentation. Fig. 1 (bars D, E and F) demonstrates that when the yeast was immobilized on Nypa fruticans leaf sheath pieces, increase in saturated fatty acid (C16:0 and C18:0) mass fraction and reduction in unsaturated fatty acid (C16:1 and C18:1) mass fraction were also observed at the end of the fermentation in the medium with and without ethanol addition. These changes were similar to those when free yeast was used. It was reported that the mass fractions of palmitic and stearic acids of the immobilized yeast on sintered glass beads increased while that of palmitoleic and oleic acids decreased when the ethanol fermentation was performed in the medium without ethanol addition (26).

The degree of unsaturation of fatty acids in cellular membrane of the immobilized and free yeast was also calculated. Fig. 2 shows that at the beginning of the fermentation, the free yeast exhibited higher degree of unsatura-

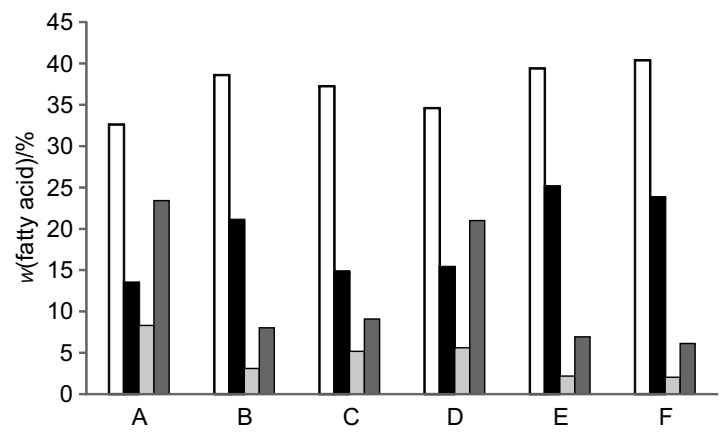

Fig. 1. Mass fractions of fatty acids in the cellular membrane of free (A, B and C) and immobilized (D, E and F) yeast; (A, D): at the beginning of fermentation; $(B, E)$ : the end of fermentation $\left(\gamma(\text { ethanol })_{\text {initial }}=0 \mathrm{~g} / \mathrm{L}\right)$; and $(\mathrm{C}, \mathrm{F})$ : the end of fermentation $(\gamma($ etha$\left.\mathrm{nol})_{\text {initial }}=47.4 \mathrm{~g} / \mathrm{L}\right)(\square$ : palmitic acid; $\square$ : stearic acid; $\square$ : palmitoleic acid; $\square$ : oleic acid)

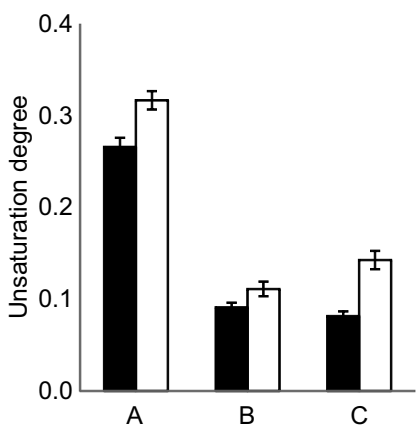

Fig. 2. Unsaturation degree of fatty acids in the cellular membrane of the immobilized $(\boldsymbol{\square})$ and free $(\square)$ yeast Saccharomyces cerevisiae; (A): at the beginning of fermentation; (B): the end of fermentation $\left(\gamma(\text { ethanol })_{\text {initial }}=0 \mathrm{~g} / \mathrm{L}\right)$; and $(\mathrm{C})$ : the end of fermentation $\left(\gamma(\text { ethanol })_{\text {initial }}=47.4 \mathrm{~g} / \mathrm{L}\right)$

tion than the immobilized yeast. Hence, it can be noted that the adsorption of yeast cells on Nypa fruticans leaf sheath pieces in the nutritional medium reduced the degree of unsaturation of fatty acids in the cellular membrane of $S$. cerevisiae cells. In addition, at the end of the fermentation, the free yeast also demonstrated higher level of unsaturation than the immobilized yeast; this phenomenon was observed in the medium with and without added ethanol. Similar results were also mentioned in a previous study (26) when the medium without ethanol addition was used for ethanol fermentation with immobilized yeast on sintered glass beads. It was reported that low degree of unsaturation of fatty acids in cellular membrane is associated with high fermentation rates of the immobilized yeast (26).

\section{Conclusion}

Increase in the initial ethanol concentration from 23.7 to $94.7 \mathrm{~g} / \mathrm{L}$ decreased the growth of and ethanol formation by the immobilized cells of Saccharomyces cerevisiae. The immobilized yeast on Nypa fruticans leaf sheath pieces showed better fermentation performance than the free yeast under ethanol stress. The decrease in the level of unsaturation of fatty acids in cellular membrane can be an explanation for high ethanol tolerance of the immobilized yeast.

\section{Acknowledgement}

This work was financially supported by Vietnam National University, Ho Chi Minh City (Project B2012-2011TD/HD-KHCN)

\section{References}

1. Yu J, Yue G, Zhong J, Zhang X, Tan T. Immobilization of Saccharomyces cerevisiae to modified bagasse for ethanol production. Renew Energy. 2010;35:1130-4. http://dx.doi.org/10.1016/j.renene.2009.11.045

2. Pacheco AM, Gondim DR, Gonçalves LRB. Ethanol production by fermentation using immobilized cells of Saccharomyces cerevisiae in cashew apple bagasse. Appl Biochem Biotechnol. 2010;161:209-17.

http://dx.doi.org/10.1007/s12010-009-8781-y. 
3. Liang L, Zhang Y, Zhang L, Zhu M, Liang S, Huang Y. Study of sugarcane pieces as yeast supports for ethanol production from sugarcane juice and molasses. J Ind Microb Biotechnol. 2008;35:1605-13 http://dx.doi.org/10.1007/s10295-008-0404-z

4. Kiran SN, Sridhar M, Venkateswar RL. High alcohol production by repeated batch fermentation using an immobilized osmotolerant Saccharomyces cerevisiae. J Ind Microb Biotechnol. 2000;24:222-6. http://dx.doi.org/10.1038/sj.jim.2900807

5. Maryse G, Dravko D. Wood blocks as a carrier for Saccharomyces cerevisiae used in the production of ethanol and fructose. Chem Eng J. 1996;61:233-40. http://dx.doi.org/ 10.1016/0923-0467(95)03042-5

6. Hamilton LS, Murphy DH. Use and management of Nipa palm (Nypa fruticans): a review. Econ Botany. 1988;42:20613. http://dx.doi.org/10.1007/BF02858921

7. Okoro IA, Okoro SO. Agricultural by products as green chemistry absorbents for the removal and recovery of metal ions from waste-water environments. Cont J Water Air Soil Pollut. 2011;2:15-22.

8. Norton S, Watson K, D'Amore T. Ethanol tolerance of immobilized brewers' yeast cells. Appl Microbiol Biotechnol. 1995;43:18-24. http://dx.doi.org/10.1007/BF00170616

9. Beltran G, Novo M, Guillamón JM, Mas A, Rozès N. Effect of fermentation temperature and culture media on the yeast lipid composition and wine volatile compounds. Int J Food Microbiol. 2008;121:169-77. http://dx.doi.org/10.1016/j.ijfoodmicro.2007.11.030

10. Alexandre H, Rousseaux I, Charpentier C. Relationship between ethanol tolerance, lipid composition and plasma membrane fluidity in Saccharomyces cerevisiae and Kloeckera apiculate. FEMS Microb Lett. 1994;24:17-22. http://dx.doi.org/10.1111/j.1574-6968.1994.tb07255.x

11. Sajbidor J, Ciesarova Z, Smogrovicova D. Influence of ethanol on the lipid content and fatty acid composition of Saccharomyces cerevisiae. Folia Microbiol. 1995;40:508-10. http://dx.doi.org/10.1007/BF02814733

12. AOAC Official Method 991.43. Total, soluble, and insoluble dietary fiber. Gaithersburg, MD, USA: AOAC International; 1995.

13. Vasconcelos JN, Lopes CE, França FP. Continuous ethanol production using yeast immobilized on sugar-cane stalks. Braz J Chem Eng. 2004;21:357-65. http://dx.doi.org/10.1590/S0104-66322004000300002

14. Miller GL. Use of dinitrosalicylic acid regent for determination of reducing sugar. Anal Chem. 1959;31:426-8. http://dx.doi.org/10.1021/ac60147a030

15. Sinigaglia M, Gardini F, Guerzoni MF. Relationship between thermal behaviour, fermentation performance and fatty acid composition in two strains of Saccharomyces cerevisiae. Appl Microbiol Biotechnol. 1993;39:593-8. http://dx.doi.org/10.1007/BF00205058

16. Birch RM, Walker GM. Influence of magnesium ions on heat shock and ethanol stress responses of Saccharomyces cerevisiae. Enzyme Microb Technol. 2000;26:678-87. http://dx.doi.org/10.1016/S0141-0229(00)00159-9

17. Desimone MF, Degrossi J, D'Aquino M, Diaz LE. Ethanol tol- erance in free and sol-gel immobilized Saccharomyces cerevisiae. Biotechnol Lett. 2002;24:1557-9.

http://dx.doi.org/10.1023/A:1020375321009

18. Hallsworth JE. Ethanol-induced water stress in yeast. J Ferment Bioeng. 1998;85:125-37.

http://dx.doi.org/10.1016/S0922-338X(97)86756-6

19. Krisch J, Szajani B. Ethanol and acetic acid tolerance in free and immobilized cells of Saccharomyces cerevisiae and Acetobacter acetii. Biotechnol Lett. 1997;19:525-8. http://dx.doi.org/10.1023/A:1018329118396

20. Piper PW. The heat shock and ethanol stress responses of yeast exhibit extensive similarity and functional overlap. FEMS Microb Lett. 1995;134:121-7. http://dx.doi.org/10.1111/j.1574-6968.1995.tb07925.x

21. Salmon JM, Vincent O, Mauricio JC, Bely M, Barre P. Sugar transport inhibition and apparent loss of activity in Saccharomyces cerevisiae as a major limiting factor of enological fermentations. Am J Enol Vitic. 1993;44:56-64.

22. Doran PM, Bailey JE. Effects of immobilization on growth, fermentation properties, and macromolecular composition of Saccharomyces cerevisiae attached to gelatin. Biotechnol Bioeng. 1986;28:73-87.

http://dx.doi.org/10.1002/bit.260280111

23. Vucurovic V, Razmovski R, Rebic M. A corn stem as biomaterial for Saccharomyces cerevisiae cells immobilization for the ethanol production. Chem Ind Chem Eng Q. 2008;14:235-8. http://dx.doi.org/10.2298/CICEQ0804235V

24. Baleiras Couto MM, Huis in't Veld JHJ. Influence of ethanol and temperature on the cellular fatty acid composition of Zygosaccharomyces bailii spoilage yeasts. J Appl Bacteriol. 1995;78:327-34. http://dx.doi.org/10.1111/j.1365-2672.1995.tb05033.x

25. Torija MJ, Beltran G, Novo M, Poblet M, Guillamon JM, Mas A, et al. Effects of fermentation temperature and Saccharomyces species on the cell fatty acid composition and presence of volatile compounds in wine. Int J Food Microbiol. 2003;85:127-36.

http://dx.doi.org/10.1016/S0168-1605(02)00506-8

26. Hilge-Rotmann B, Rehm HJ. Relationship between fermentation capability and fatty acid composition of free and immobilized Saccharomyces cerevisiae. Appl Microbiol Biotechnol. 1991;34:502-8. http://dx.doi.org/10.1007/BF00180578

27. You KM, Rosenfield CL, Knipple DC. Ethanol tolerance in the yeast Saccharomyces cerevisiae is dependent on cellular oleic acid content. Appl Environ Microbiol. 2003;69:14991503.

http://dx.doi.org/10.1128/AEM.69.3.1499-1503.2003

28. Chi Z, Arneborg N. Relationship between lipid composition, frequency of ethanol-induced respiratory deficient mutants, and ethanol tolerance in Saccharomyces cerevisiae. J Appl Microbiol. 1999;86:1047-52. http://dx.doi.org/10.1046/j.1365-2672.1999.00793.x

29. Beaven MJ, Charpentier C, Rose AH. Production and tolerance of ethanol in relation to phospholipid fatty-acyl composition in Saccharomyces cerevisiae NCYC 43. J Gen Microbiol. 1982;28:1447-55.

http://dx.doi.org/10.1099/00221287-128-7-1447 